wrong ideal, the people of England are people with an extraordinary sense of justice and kindness. They still retain a grasp on their old religious and ethical ideals. It is because we realize that these ideals cannot exist with the type of world domination sought by Germany that the War is being fought. Sir John emphasized the fact that a first step in the new world must be the abolition of poverty in feeding, clothing and housing, and declared that in the future biological science will be applied much faster than it has been applied in the past. We must concentrate first on building men and women-particularly women. That is more important than building new cities. That can be done by the purposeful teaching of biological science, and if we apply the ideals of biological science in our teaching we shall find we are not very far off the Christian ideal.

\section{Industrial Pest Control Association}

A meEtring of representatives of firms in all branches of the industrial pest control industry other than agriculture was held in London on June 9. The firms represented included those interested in natural insecticide raw materials such as Pyrethrum and Derris of Lonchocarpus, manufacturers of basic chemicals such as ethylene oxide and cyanides, manufacturers of speciality products for insect and rodent control, and contracting firms primarily concerned in the application of insecticides, fumigants and rodent killers on industrial premises. After consideration of the growing need for industrial pest control measures, particularly in relation to food storage and the war effort generally, it was unanimously decided to set up a fully representative body to be known as the Industrial Pest Control Association. In the past two months the new Association, with forty members, has set up a strong executive committee consisting of : Mr. C. S. Kroger of W. Edmonds and Co., Ltd. (chairman), Mr. R. G. Berchem of Jeyes Sanitary Compounds Co., Ltd., Mr. F. H. Braybrook of Technical Products, Ltd., Dr. F. P. Coyne of Imperial Chemical Industries, Ltd., Mr. A. F. McIntosh of Thos. Harley, Ltd., Mr. S. F. Sprange of London Fumigation Co., Ltd., Mr. J. B. Wilton of Fumigation Services, Ltd., Dr. E. Holmes of Plant Protection, Ltd. (hon. secretary). In addition, a small technical sub-committee has been set up, with powers to co-opt other representatives with special knowledge, to advise the Association on technical matters and to collaborate with Government departments and other bodies on matters of mutual interest. Inquiries should be addressed to the honorary secretary of the Association at Jealott's Hill, Bracknell, Berks.

\section{Sir William Tilden, F.R.S. (1842-1926)}

Srr William AUgustus Tilden, the centenary of whose birth falls on August 15, is best remembered as an inspiring teacher and for his pioneering work in connexion with scientific teaching in the younger universities of Great Britain. At twenty-two he became a demonstrator in chemistry at the Pharmaceutical Society, at thirty science master at Clifton College, at thirty-six professor of chemistry and metallurgy in Mason College, Birmingham, and at fifty-two he succeeded Sir Edward Thorpe in the chair of chemistry at the Royal College of Science, London. He retired in 1909. Tilden himself wrote some autobiographical notes on his school days and his efforts to qualify as a teacher of science in an article entitled "Progress in Science Teaching", published in the Jubilee issue of Nature (Nov. 6, 1919); while in his biography of Sir William Ramsay (1918) are to be found accounts of the movement by which Ramsay, Tilden and others in 1889 secured a Government grant of $£ 15,000$ for the university colleges of Great Britain. Tilden's books were mainly for the use of teachers and students, but he also wrote some on the history of chemistry. He published some sixty scientific papers. So early as 1884, in his study of the terpenes, he obtained a liquid isoprene which by contact with gaseous hydrochloric acid was partly converted to rubber.

Tilden was president of the Institute of Chemistry during 1891-94 and president of the Chemical Society during 1903-5. He delivered the Bakerian Lecture to the Royal Society in 1900 and eight years later received the Davy Medal. When presented with the Medal he remarked that "In the life of every true scientific man there came sooner of later a time when if he had the smallest amount of success he felt disposed like Archimedes to rush into the street and shout Eureka! Eureka! Those were the moments of real triumph, the moments when one felt that life held something that was very sweet". Tilden, who was born in London and was the son of a Bank of England official, was twice married, and died on December 11, 1926, at Northwood, Middlesex, in his eighty-fourth year.

\section{A Founder of the Royal Horticultural Society}

The Royal Horticultural Society was founded at a meeting on March 7, 1804, at Mr. Hatchard's house in Piccadilly. First among the names of those present was the Right Hon. Charles Greville, whose biography forms the subject of a paper by the present assistant secretary of the Society (J. Roy. Hort. Soc., 67, Pt. 7 ; July, 1942). Born in 1749, he was a friend of Emma Lyon, later the Lady Hamilton who was associated with Nelson, had a distinguished career in Parliament, built harbour works at Milford Haven, became a fellow of the Royal Society for his work in geology, and practised such wide cultural graces as are denoted by membership of the Society of Dilettanti. Among all this extensive interest he managed to make a specialist contribution to horticulture, being responsible for the introduction of Lilium concolor, Pconia suffruticosa rosea, Camellia japonica, Clinogyne dichotoma, two varieties of Magnolia, and others. Greville's garden near Paddington is said to be the place where American blight first appeared, but its owner overeame this doubtful distinction by suggesting the spraying of fruit trees with lime-wash. The genus Grevillea was named in honour of this horticultural pioneer by Robert Brown.

\section{Prevention of Heart Disease}

IN a recent paper (Bol. Of. San. Panamericana, 21, 231 ; 1942), Dr. Hugo J. D'Amato, secretary of the National Department of Hygiene at Buenos Aires, states that diseases of the heart and circulatory system were responsible for 24 per cent of the deaths in Buenos Aires in 1939. A fourfold programme has therefore been devised involving respectively medical prophylaxis and care, influence on specific groups, and economic losses, social assistance and State action. As regards the first point, medical examinations are to be made in such centres as factories, government offices and schools, so that 